This is a post-peer-review, pre-copyedit version of an article published in Environmental Geochemistry and Health.

The final authenticated version is available online at: https://doi.org/10.1007/s10653-020-00599-y 


\title{
Arsenic in the rock-soil-plant system and related health risk in a magmatic-metamorphic belt, West of Iran
}

\author{
Meisam Rastegari Mehr ${ }^{a^{*}}$, Behnam Keshavarzi $^{b^{*}}$, Farid Moore ${ }^{\mathrm{b}}$, Peter S. Hooda ${ }^{\mathrm{c}}$, Rosa \\ Busquets $^{\mathrm{c}}$, Zohreh Ghorbani ${ }^{\mathrm{d}}$
}

\begin{abstract}
${ }^{\text {a }}$ Department of Applied Geology, Faculty of Earth Science, Kharazmi University, Tehran, 15614, Iran
${ }^{\mathrm{b}}$ Department of Earth Sciences, College of Sciences, Shiraz University, Shiraz, 71454, Iran

${ }^{c}$ School of Geography, Geology and the Environment, Kingston University London, Kingston Upon Thames KT1

2EE, UK

${ }^{\mathrm{d}}$ Department of Earth Sciences, University of Western Ontario, 1151 Richmond St, London, Ontario, N6A 5B7, Canada
\end{abstract}

*Corresponding authors;

Behnam Keshavarzi: Tel/fax:+98 71 32284572; E-mail address: bkeshavarzi@shirazu.ac.ir Meisam Rastegari Mehr: Tel/Fax: +98 26 34511000; E-mail address: rastegar.m@khu.ac.ir

\begin{abstract}
Following earlier reports of water contamination and arsenic (As) toxicity symptoms in residents of Kurdistan Province, As was determined in rock, soil and plant samples to investigate its fate from rock to crops and its potential effects on human health. Total As content ranged from 4.9 to $10044 \mathrm{mg} / \mathrm{kg}, 7.7$ to $429.5 \mathrm{mg} / \mathrm{kg}$ and $<0.05$ to $25079 \mu \mathrm{g} / \mathrm{kg}$ (dry weight) in rock, soil and plant samples, respectively. The Qorveh-Bijar region data indicated that magmatic differentiation has enriched late magmatic fluids in As. High rare earth elements concentration, dissociation coefficient, and positive Eu anomaly in volcanic rocks, indicated the prevalence of intermediate to felsic composition. The highest As concentration was measured in travertine. In soil, As average level in Qorveh and Bijar was 48.50 and $106.60 \mathrm{mg} / \mathrm{kg}$, respectively. Higher pollution index (PI) and geoaccumulation index ( $\left.\mathrm{I}_{\mathrm{geo}}\right)$ were also calculated for Bijar County. The As concentration in crop samples was greater than the recommended maximum permissible concentration for foodstuff. Mann-Whitney $U$ test revealed significant differences between As concentration in different plant species and no difference between plants in Bijar and Qorveh. Also, alfalfa displayed the highest biological accumulation coefficient among the investigated plants. The calculated chronic daily intake of As in Bijar County was higher than the recommended levels for wheat and barley grains. Moreover, the hazard quotient (HQ) and incremental lifetime cancer risk assessments revealed high non-cancer (HQ $>1$ for both adults and children) and cancer (particularly for barley in Bijar) risks for inhabitants via consumption of As contaminated crops cultivated in the study area.
\end{abstract}

Keywords: Arsenic; Rock; Soil; Plant; Bijar; Qorveh 


\section{Introduction}

Rocks enriched in arsenic (As) can release As, and this metalloid may enter a more actice biogeochemical cycle, posing risk to ecosystems (Dradrach et al. 2020). The As average concentration in Earth's crust, igneous rocks and sedimentary rocks rage from 0.5-2.5, 0.5-2.5 and 1-13 $\mathrm{mg} / \mathrm{kg}$, respectively, which may be associated with several minerals, including arsenite minerals, arsenopyrite, orpiment, realgar, and some other polymorphous types of minerals. The geochemical behavior of As (V) is similar to that of phosphates because of their similar ionic radii (Kabata-Pendias and Mukherjee 2007). Over time, rock weathering can release As and other elements, maintaining a steady supply of macro- and micro- nutrients, and some toxic elements, to soil (Myrvang et al. 2016). The predominant forms of arsenic in soil solution are mainly anionic including $\mathrm{AsO}^{2-}, \mathrm{HAsO}_{4}{ }^{2-}$ and $\mathrm{H}_{2} \mathrm{AsO}_{3}{ }^{2-}$ (Kabata-Pendias and Sadurski 2004), largely mediated by soil characteristics, in particular Eh-pH influences. As forms, in turn, affect its sorptiondesorption in soils (Bissen and Frimmel 2003), influencing its uptake by plants. In food crops, As uptake is highly variable, commonly ranging from $10-60 \mu \mathrm{g} \mathrm{kg}^{-1}$, depending upon its natural soil concentration, soil properties and plant species, and appears to increase in green vegetables and plants grown in contaminated soils (Kabata-Pendias and Mukherjee 2007).

Epidemiological evidence so far has revealed the relationship between long-term chronic As exposure and increased risks of various cancers, diabetes mellitus, cardio-vascular disease, ocular disease and neuropathies (States et al. 2008; Kundu et al. 2011; Rana et al. 2012; Keshavarzi et al. 2015a). Most reported studies in literature have focused on anthropogenic sources of As contamination in water and soil, including mining and smelting, application of arsenic-containing pesticides, herbicides and fertilizers, wood preservatives, arsenic additives in livestock feeds, electronic industries, pharmaceutical works, galvanizing and ammunition factories, and coal or petroleum combustion (Ongley et al. 2007; Lee et al. 2008; Liu et al. 2010). Also, As contamination of groundwater by geogenic sources is reported from various regions around the world (Ahmed et al. 2001; Bhattacharya et al. 2007; Kumar et al. 2016; Sharifi et al. 2017).

Naturally high levels of As in groundwater cause various diseases in human and constitutes a highpriority water quality problem, particularly in Asian countries, including India, Bangladesh, Pakistan and Iran (Kumar et al. 2018; Nickson et al. 2005; Rahman et al. 2011; Keshavarzi et al. 2011). On the other hand, it is generally accepted that soil-plant transfer of As is a principal pathway of human exposure to As, particularly in regions where drinking/ground water As levels do not exceed the WHO drinking water standard of $10 \mu \mathrm{g} \mathrm{As} / \mathrm{L}$. Arsenic inputs in soils either through the use of As-containing water for irrigation purposes or weathering of As-rich rocks could accumulate in the soil and consequently be leached into ground and/or surface waters. Soil arsenic may also be metabolized and possibly volatilized by microorganisms and be taken up by crops from the soil-water system (Martin et al. 2014). The role of As-contaminated groundwater or springs which are used for cropland irrigation, elevating soil As, and consequently resulting in crops contamination, is widely acknowledged (e.g. Rahman et al. 2013; Chen et al. 2014; Farooq et al. 2019).

The plant availability of soil arsenic is determined by soil properties, notably mineral composition, organic matter content, $\mathrm{pH}$ and redox potential (Tu and Ma 2003; Warren et al. 2003). However, soil total arsenic content remains a key factor affecting its uptake by food crops. Most studies have focused on the biogeochemistry of arsenic in soils with anthropogenically elevated arsenic concentrations (e.g. Smith et al. 2009; Otones et al. 2011; Adamo et al. 2014; Mathee et al. 2018). 
Some soils naturally can have high levels of arsenic due to the mineralogy of their parent materials (Wang et al. 2015), which may pose risk to human health via uptake by food crops. It is therefore important to understand the behavior of arsenic in the rock-soil-plant system to better assess its entry in the food-chain and the risk it may pose to human health.

Various arsenic toxicity health effects are widely documented from Kurdistan Province in west of Iran located in the so-called northern Sanandaj-Sirjan magmatic-metamorphic belt. Mosaferi et al. (2008) studied the prevalence of skin lesions among residents in Kurdistan province in Iran with emphasis on intake of arsenic from drinking water. They found a significant relationship between total lifetime intake of arsenic from drinking water and hyperkeratosis and hyperpigmentation. Barati et al. (2010) measured 42 to $1500 \mu \mathrm{g} / \mathrm{L}$ arsenic in drinking water in Western Iran. The results of their study revealed that there was a significant correlation between exposure to arsenic and arsenic poisoning in inhabitants, and Mee's line was the dominant disorder in the study area. Keshavarzi et al. (2015a) reported anemia and liver damage in sheep population exposed to As via drinking water and fodder in Kurdistan Province. Karimi et al. (2019) suggested that weathering and degradation of the ultramafic rocks in the West of Iran will increase the concentration of heavy metals including $\mathrm{Ni}, \mathrm{Cr}, \mathrm{Co}, \mathrm{Pb}$ and $\mathrm{V}$ in soil, and subsequently can pose environmental hazards. Sharifi et al. (2017) investigated the relationship between soil As and its accumulation in vegetables in some villages of Kurdistan Province, and reported high hazard quotients particularly for consumption of root and tuber crops. Wheat (mainly Triticale, Bahar, Saionz, Falat, Chamran, Pishtaz, Sepahan, Pishgam, and Tous varieties) and barley (Bahman, Makooei, Reyhan, Nosrat, Fajer and Kavir varieties) bread, have a large share in the diet of people in Iran (Pourreza et al. 2012; Ghezeljeh et al. 2011). The majority of the studies in this region has shown that the main source of As is geogenic, particularly igneous rocks and travertine deposits (Nasrabadi and Bidabad, 2013; Sharifi et al. 2017; Karimi et al. 2019). However, it is not entirely clear whether the source of elevated As accumulation in food crops in this region is its natural occurrence in the soils or the use of groundwater that in this region contains high levels of As (Mosaferi et al. 2008; Barati et al. 2010; Keshavarzi et al. 2011). The main objectives of this study were: a) to investigate the relationship between arsenic in rock, soil and plants, b) to determine the degree to which selected soils and crops are contaminated with naturally occurring As, and c) to assess the risk of local residents' exposure to As through consumption of local food crops.

\section{Materials and Methods}

\subsection{Geological setting of the study area}

Kurdistan Province with an area of $29,137 \mathrm{~km}^{2}$ is located in the West of Iran between $34^{\circ} 45^{\prime}-36^{\circ}$ $28^{\prime} \mathrm{N}$ and $45^{\circ} 34^{\prime}-48^{\circ} 14^{\prime} \mathrm{E}$. The local climate is characterized with an average annual precipitation and humidity of $480 \mathrm{~mm}$ and $47 \%$, respectively. The average annual temperature is $6.13{ }^{\circ} \mathrm{C}$, peaking in July $\left(32^{\circ} \mathrm{C}\right)$ and the minimum temperature in January $\left(-3^{\circ} \mathrm{C}\right)$. The focus of this study is on a part of the so-called Northern Sanandaj-Sirjan magmatic-metamorphic belt, east of Kurdistan Province, and includes Qorveh and Bijar counties covering $4900 \mathrm{~km}^{2}$ and with populations of 260,961 and 93,714, respectively. The exposed geological units in this sector are mostly sedimentary rocks with andesitic, basaltic and travertine outcrops (Fig 1). Widespread travertine deposits cover the volcanic rocks and represent the waning stages of TertiaryQuaternary volcanic activity (Boni et al. 2007). Travertine springs in the study area are related to the basic volcanoes that extend from North West to South East. The spring's pathway is probably 
fractures connected to deep active hydrothermal systems. The travertine deposits are intensely fractured and contain numerous springs probably related to hydrothermal fluid circulation (Keshavarzi et al. 2011).

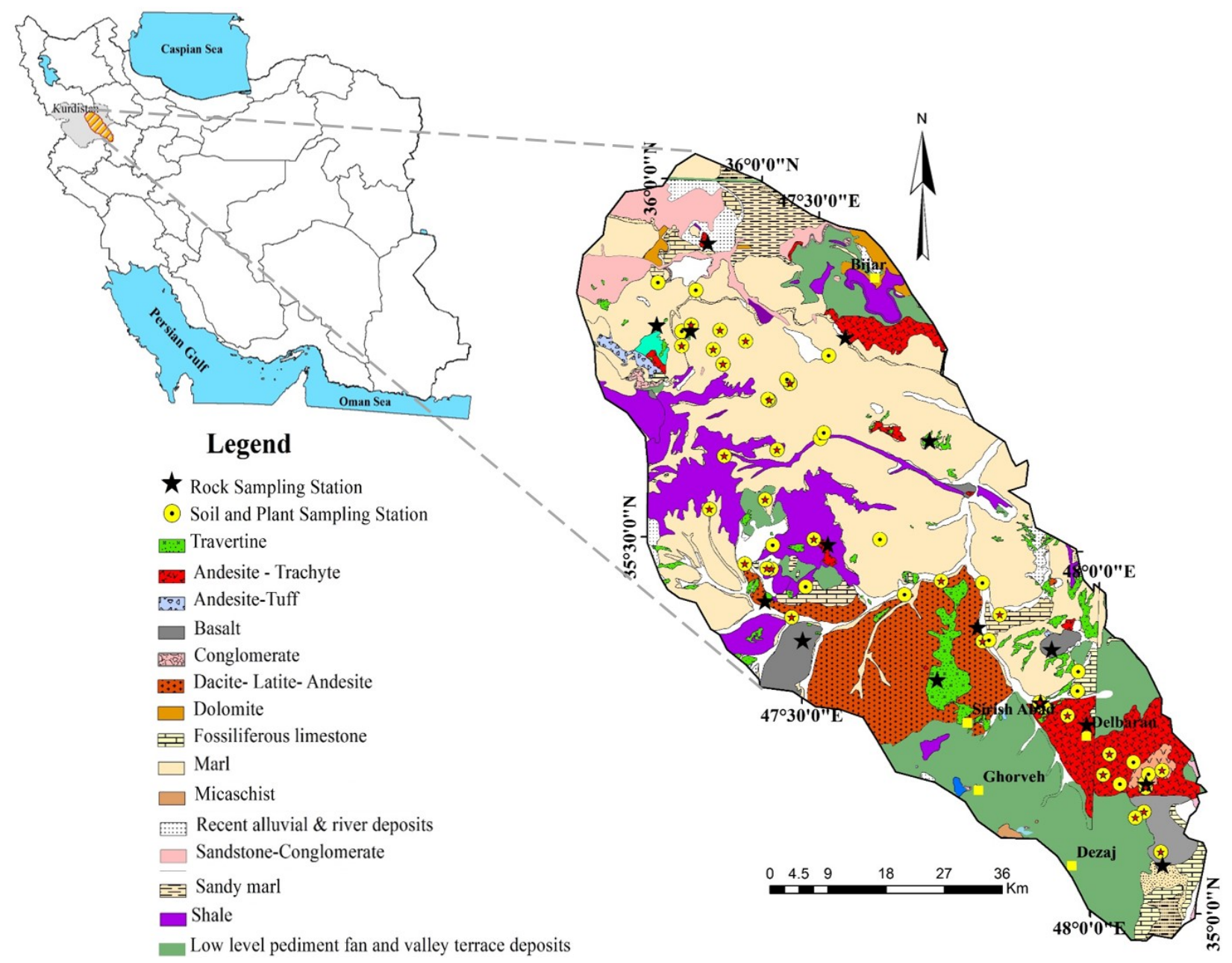

Figure 1. Geological map of the study area, showing sampling stations.

\subsection{Sampling and analyses}

A total of 16 rock samples (travertine, basalt and intermediate volcanic rocks), 51 crop field topsoil $(0-10 \mathrm{~cm})$ samples and 58 crop samples (28 samples of wheat grain, 16 samples of barley grain and 14 samples of alfalfa stem and leaves) were collected at harvest time. It should be noted that alfalfa fields are irrigated but wheat and barley are cultivated by dry farming. Small chips of rock were broken off from different outcrops in the study area. The rock sampling stations were determined in such a way that all major outcrops as well as all parts of the study area are covered. The rock chips free of veining and alteration, were collected in sealable plastic bags, labeled and transferred to the laboratory. In the laboratory the rock samples were crushed to powder using a 
grinder (Tema Machinery Ltd. UK, model T 750), analyzed for arsenic and rare earth elements by Inductively Coupled- Mass Spectrometry (Perkin Elmer Sciex Elan 6100 ICP-MS System), following microwave-assisted digestion (CEM, model Mars 6) $\left(\mathrm{T}=180{ }^{\circ} \mathrm{C}\right)$ in Aqua Regia, following sample preparation and quality assurance protocols.

The soil sampling locations were chosen based on their cultivated crops and proximity to the sampled rock outcrops, including travertine, basalt, andesite and latite. To obtain representative samples from each agricultural soil sampling site, composite soil samples were taken. For this purpose, each sampled field was divided into 10 similar size portions, and 10-15 randomly selected soil samples were collected from each portion (at 0-20 cm in depth) using an auger and a plastic scoop and placed in a bucket. The samples were mixed thoroughly, quartering was achieved by splitting the thoroughly mixed sample into four equal parts, two opposite quarters were discarded, and the remaining quarters were remixed, and the process repeated until the desired sample size ( 1 $\mathrm{kg}$ ) was obtained. The collected samples were kept in polyethylene bags and transported to the laboratory for preparation and analysis. The soil samples were air dried at room temperature and sieved through a $63 \mu \mathrm{m}$ sieve for the analyses. Total As concentrations were measured using ICPMS following microwave-assisted digestion with aqua regia. Crop samples were collected freshly from the same fields where the soil samples were collected (Sharma et al. 2020). Six sub-samples of wheat, barley and alfalfa were collected at each sampling site, and then, aggregated into one sample for further treatment (Bhattacharya et al. 2010). The samples were transported to the laboratory, cleaned with deionized water, and air dried. Crop samples were then ground in a precleaned stainless steel grinder and passed through a $250 \mu \mathrm{m}$ sieve. The finely ground crop plant/grain powder was then stored in polythene zipped bags. The powdered plant samples were digested in a microwave digester (with a mixture of hydrochloric acid, nitric acid and hydrogen peroxide, the solution was cooled by $25 \mathrm{~mL}$ double distilled water, filtered through No. 1 Whatman filter (Sharma et al.2020), and then analyzed by ICP-MS. All the rock, soil and plant samples analyses were performed in the Labwest Analytical Laboratories, Perth, Western Australia.

For quality assurance and quality control purposes, standard reference materials, sample replicates and method blanks were used. The successive dilution of reference standard solutions (STD OREAS45EA and STD CDV-1) was applied to prepare the calibration curve in $2 \%(\mathrm{v} / \mathrm{v}) 1 \mathrm{~N}$ nitric acid. During the analysis, the appropriate conditions were maintained based on Kumar et al. (2020). Results showed that the recovery percentages ranged from $89-106 \%$, relative standard deviation was less than 7\% for each element, and the blanks were below the detection limit (50 $\mu \mathrm{g} / \mathrm{kg})$.

\subsection{Data analysis}

\subsubsection{Pollution Index (PI)}

Soil arsenic pollution was evaluated using the pollution index $\left(\mathrm{PI}_{\mathrm{i}}\right)$, calculated as the ratio between the As concentration $\left(\mathrm{C}_{\mathrm{i}}\right)$ in a soil sample and its reference value $\left(\mathrm{S}_{\mathrm{i}}\right)(\mathrm{Hu}$ et al. 2013):

$$
\mathrm{PI}_{\mathrm{i}}=\frac{\mathrm{C}_{\mathrm{i}}}{\mathrm{S}_{\mathrm{i}}}
$$


In this study, soil quality guideline of $12 \mathrm{mg} \mathrm{As} / \mathrm{kg}$ (CCME 2007) was used as the reference value $\left(\mathrm{S}_{\mathrm{i}}\right)$ to calculate the pollution index.

\subsubsection{Index of geoaccumulation (Igeo)}

Another approach for assessing the contamination level of soil is the geoaccumulation ( $\mathrm{Igeo}_{\text {geo }}$ index according to Equation 2 (Zhang et al. 2016):

$$
\mathrm{Igeo}_{\mathrm{geg}} \log _{2}\left(\mathrm{C}_{\mathrm{n}} / 1.5 \times \mathrm{B}_{\mathrm{n}}\right)
$$

The main difference between this index and PI is that the effect of lithology is limited by a correction factor. In Equation 2, $\mathrm{C}_{\mathrm{n}}$ is the measured total concentration of As in the soil sample, $\mathrm{B}_{\mathrm{n}}$ is reference value, and 1.5 is the factor compensating for background data (correction factor) related to lithogenic effects. In this study, mean As concentration in world soils $(6 \mathrm{mg} / \mathrm{kg}) \mathrm{was}$ used as reference (Adriano et al. 2001). Igeo $<0$ indicates practically unpolluted, 0.01-1 is unpolluted to moderately polluted, 1.01-2 is moderately polluted, 2.01- 3 is moderately to strongly polluted, 3.01-4 is strongly polluted, 4.01-5 is strongly to extremely polluted and Igeo $>5$ shows extremely polluted soil (Qing et al. 2015; Amjadian et al. 2018).

\subsubsection{Biological absorption coefficient (BAC)}

Biological absorption coefficient was used to examine the transfer of As from soil to plant. It was calculated as proposed by Edwards et al. (1998) as follows:

$$
\mathrm{BAC}=\frac{c_{p}}{C_{s}}
$$

Where $C_{p}$ is the arsenic concentration in the plant and $C_{s}$ is its concentration in the soil.

\subsubsection{Health risk assessment}

The United States Environmental Protection Agency developed a model to assess human health risk. In this study, the model was used to evaluate the risks posed by As via consumption of cultivated food crops. Hazard Quotient (HQ) expressing potential non-cancer risk for As was calculated as follows (USEPA 1989):

$$
H Q=\frac{C D I}{R f D o}
$$




$$
C D I=\frac{C M \times I R \times E F \times E D}{B W \times A T}
$$

where chronic daily intake (CDI) and oral reference dose (RfDo) have the same unit (mg $\mathrm{kg}^{-1}$ day $\left.^{-1}\right)$; CM is the average values of total As concentrations in crop plants $\left(\mathrm{mg} \mathrm{kg}^{-1}\right)$; IR is the crop ingestion rate $\left(\mathrm{kg} \mathrm{person}^{-1}\right.$ day $\left.^{-1}\right)$; exposure frequency $(\mathrm{EF})$ is 350 days year ${ }^{-1}$; exposure duration (ED) was taken 70 years for adults and 6 years for children; BW is body weight, $70 \mathrm{~kg}$ for adults and $20 \mathrm{~kg}$ for children; AT is the average exposure time $\left(\mathrm{ED} \times 365\right.$ days year $\left.{ }^{-1}\right)$; and the RfDo value for As is $3 \times 10^{-4} \mathrm{mg} \mathrm{kg}^{-1} \mathrm{day}^{-1}$ (USEPA 1998). The exposed population is assumed to face no potential risk when HQ is below unity (USEPA 2000; Huang et al. 2008; Keshavarzi et al. 2015b).

In addition, in order to determine the cancer hazard, incremental life-time cancer risk (ILTCR) was calculated using the following equation (USEPA 1998; Halder et al. 2014):

$$
\mathrm{ILTCR}=\frac{C_{T} A s \times I R \times C F \times E F \times E D}{B W \times A T} \times C S F
$$

where $\mathrm{C}_{\mathrm{T}} \mathrm{As}$ is the upper limit of the $95 \%$ confidence interval for the mean (95\% UCL) in crop plants, $\mathrm{CF}$ is conversion factor $\left(0.085 \mathrm{mg} \mathrm{kg}{ }^{-1}\right)$ and CSF is the cancer slope factor $\left(1.5 \mathrm{mg} \mathrm{kg}^{-1}\right.$ day $^{-1}$ and $4.5 \mathrm{mg} \mathrm{kg}^{-1} \mathrm{day}^{-1}$ for adults and children, respectively) (Sharifi et al. 2017). The acceptable risk range for carcinogens is set as $10^{-6}$ to $10^{-4}$ by the USEPA (USEPA 2001). Additional action is required to reduce the exposure and resulting risk for ILTCR above $10^{-4}$ (USEPA 2008).

In this study, the chronic daily intake and hazard quotient (HQ) were calculated to evaluate the potential human health risks in the study area. Alfalfa was not considered in this evaluation as only wheat and barley grains are consumed by human in the region. However, we acknowledge that elevated As concentrations in alfalfa present indirect risk to human health via the plant-animalhuman food-chain. Since bread forms a large part of the diet in Iran, per capita ingestion rate of wheat and barley in the study area were estimated as 500 and $200 \mathrm{~g} /$ day for adults and children, respectively (Sharifi et al. 2017).

\subsubsection{Statistical analysis}

Statistical analyses were carried out using SPSS 19 software package. The normality of As concentration was assessed using the Kolmogrov-Smirnov normality test $(\mathrm{p}>0.01)$. The data were found not normally distributed, therefore, the effects of the sampling site (Qorveh and Bijar Counties) and plant species on As concentration in plant samples were evaluated by the MannWhitney $U$ test which is considered as nonparametric alternative to the independent $t$-test. Also, As concentration in soil samples collected from fields in close proximity of the four main rock types in the study area was compared using Kruskal-Wallis H test.

\section{Results and discussion}

\subsection{Source of arsenic in rock samples}


The concentration of As and REEs in different rock samples are presented in Table 1.

Table 1. Arsenic and REEs concentrations in the analyzed rock samples $(\mathrm{mg} / \mathrm{kg}) \pm \mathrm{SD}$.

\begin{tabular}{|c|c|c|c|c|c|c|c|c|c|c|}
\hline Sample ID & Rock type & As & La & $\mathrm{Ce}$ & $\operatorname{Pr}$ & Nd & Sm & Eu & Gd & Tb \\
\hline \multicolumn{2}{|c|}{ Limit of detection } & 0.5 & 0.05 & 0.05 & 0.02 & 0.02 & 0.02 & 0.02 & 0.02 & 0.02 \\
\hline $\mathrm{R} 1$ & Andesite & $45.6 \pm 0.6$ & $64.4 \pm 0.1$ & $113 \pm 0.07$ & $12.5 \pm 0.02$ & $44 \pm 0.1$ & $6.64 \pm 0.03$ & $1.7 \pm 0.01$ & $5.04 \pm 0.04$ & $0.72 \pm 0.03$ \\
\hline $\mathrm{R} 2$ & Andesite & $46.8 \pm 0.7$ & $62.6 \pm 0.05$ & $114 \pm 0.1$ & $13 \pm 0.03$ & $46 \pm 0.02$ & $7.16 \pm 0.02$ & $1.76 \pm 0.02$ & $5.79 \pm 0.04$ & $0.84 \pm 0.03$ \\
\hline R3 & $\begin{array}{c}\text { Nepheline } \\
\text { trachyte }\end{array}$ & $82.7 \pm 0.5$ & $108 \pm 0.03$ & $176 \pm 0.2$ & $19.1 \pm 0.02$ & $66.6 \pm 0.04$ & $10 \pm 0.05$ & $2.5 \pm 0.03$ & $7.59 \pm 0.02$ & $1.03 \pm 0.04$ \\
\hline $\mathrm{R} 4$ & Andesite & $57.4 \pm 0.6$ & $67 \pm 0.06$ & $114 \pm 0.2$ & $12.8 \pm 0.03$ & $44.3 \pm 0.01$ & $6.64 \pm 0.03$ & $1.74 \pm 0.06$ & $5.39 \pm 0.02$ & $0.81 \pm 0.02$ \\
\hline R5 & Andesite & $49.3 \pm 0.7$ & $40 \pm 0.1$ & $70 \pm 0.05$ & $8.34 \pm 0.02$ & $29.6 \pm 0.03$ & $4.85 \pm 0.02$ & $1.27 \pm 0.02$ & $3.85 \pm 0.02$ & $0.55 \pm 0.02$ \\
\hline R6 & Andesite & $44.1 \pm 0.5$ & $65.6 \pm 0.05$ & $115 \pm 0.1$ & $12.5 \pm 0.04$ & $44 \pm 0.02$ & $6.83 \pm 0.03$ & $1.65 \pm 0.02$ & $5.27 \pm 0.03$ & $0.76 \pm 0.03$ \\
\hline R7 & Trachyte & $4.9 \pm 0.5$ & $49.5 \pm 0.05$ & $89.1 \pm 0.1$ & $10.2 \pm 0.04$ & $36.9 \pm 0.02$ & $6.19 \pm 0.03$ & $1.62 \pm 0.02$ & $5.19 \pm 0.03$ & $0.78 \pm 0.04$ \\
\hline $\mathrm{R} 8$ & Latite & $5140 \pm 2$ & $60 \pm 0.05$ & $120 \pm 0.2$ & $15.7 \pm 0.1$ & $63.9 \pm 0.05$ & $10.8 \pm 0.04$ & $2.46 \pm 0.04$ & $7.48 \pm 0.02$ & $0.93 \pm 0.03$ \\
\hline R9 & $\begin{array}{l}\text { Nepheline } \\
\text { latite }\end{array}$ & $62.3 \pm 0.7$ & $37.3 \pm 0.02$ & $62.4 \pm 0.06$ & $7.4 \pm 0.03$ & $26 \pm 0.03$ & $4.14 \pm 0.02$ & $1.13 \pm 0.03$ & $3.21 \pm 0.02$ & $0.44 \pm 0.02$ \\
\hline $\mathrm{R} 10$ & Basalt & $6.5 \pm 0.5$ & $103 \pm 0.5$ & $181 \pm 0.1$ & $20.3 \pm 0.01$ & $75.1 \pm 0.05$ & $10.8 \pm 0.03$ & $2.98 \pm 0.03$ & $8.39 \pm 0.05$ & $1.1 \pm 0.05$ \\
\hline R11 & Basalt & $8.1 \pm 0.5$ & $134 \pm 0.3$ & $249 \pm 0.1$ & $28.7 \pm 0.1$ & $110 \pm 0.01$ & $15.3 \pm 0.04$ & $4.03 \pm 0.05$ & $10.6 \pm 0.03$ & $1.22 \pm 0.03$ \\
\hline $\mathrm{R} 12$ & Travertine & $>10000$ & $1.38 \pm 0.01$ & $2.6 \pm 0.05$ & $0.29 \pm 0.02$ & $1.13 \pm 0.02$ & $0.02 \pm 0.001$ & $0.06 \pm 0.01$ & $0.21 \pm 0.02$ & $0.03 \pm 0.001$ \\
\hline $\mathrm{R} 13$ & Travertine & $562 \pm 1$ & $0.09 \pm 0.01$ & $0.65 \pm 0.05$ & $0.04 \pm 0.01$ & $0.06 \pm 0.01$ & $0.2 \pm 0.01$ & $0.02 \pm 0.001$ & $0.05 \pm 0.001$ & $0.02 \pm 0.001$ \\
\hline R14 & Travertine & $>10000$ & $1.22 \pm 0.02$ & $2.05 \pm 0.06$ & $0.26 \pm 0.01$ & $1.02 \pm 0.02$ & $0.1 \pm 0.001$ & $0.04 \pm 0.001$ & $0.1 \pm 0.001$ & $0.02 \pm 0.001$ \\
\hline $\mathrm{R} 15$ & Travertine & $>10000$ & $0.84 \pm 0.02$ & $1.28 \pm 0.05$ & $0.16 \pm 0.01$ & $0.61 \pm 0.02$ & $0.17 \pm 0.001$ & $0.02 \pm 0.001$ & $0.06 \pm 0.001$ & $0.02 \pm 0.001$ \\
\hline R16 & Travertine & $>10000$ & $1.13 \pm 0.01$ & $1.89 \pm 0.07$ & $0.25 \pm 0.01$ & $0.94 \pm 0.02$ & $0.2 \pm 0.001$ & $0.02 \pm 0.001$ & $0.1 \pm 0.001$ & $0.02 \pm 0.001$ \\
\hline Sample ID & Rock type & Dy & Ho & $\mathbf{E r}$ & $\mathbf{T m}$ & $\mathbf{Y b}$ & Lu & $\sum \mathbf{R E E}$ & $(\mathbf{L a} / \mathbf{L u}) \mathbf{N}$ & $(\mathbf{E u}) /\left(\mathbf{E} \mathbf{u}^{*}\right)$ \\
\hline \multicolumn{2}{|c|}{ Limit of detection } & 0.02 & 0.02 & 0.02 & 0.02 & 0.02 & 0.02 & - & - & - \\
\hline $\mathrm{R} 1$ & Andesite & $3.43 \pm 0.02$ & $0.65 \pm 0.02$ & $1.67 \pm 0.04$ & $0.28 \pm 0.02$ & $1.54 \pm 0.05$ & $0.38 \pm 0.02$ & 255.95 & 16.9 & 0.9 \\
\hline $\mathrm{R} 2$ & Andesite & $4.25 \pm 0.04$ & $0.81 \pm 0.02$ & $2.11 \pm 0.06$ & $0.36 \pm 0.02$ & $2.03 \pm 0.05$ & $0.36 \pm 0.02$ & 261.07 & 17.4 & 0.84 \\
\hline R3 & $\begin{array}{c}\text { Nepheline } \\
\text { trachyte }\end{array}$ & $4.74 \pm 0.05$ & $0.85 \pm 0.03$ & $2.24 \pm 0.04$ & $0.38 \pm 0.02$ & $2.23 \pm 0.04$ & $0.36 \pm 0.03$ & 401.62 & 30 & 0.88 \\
\hline $\mathrm{R} 4$ & Andesite & $3.94 \pm 0.04$ & $0.79 \pm 0.03$ & $2.03 \pm 0.04$ & $0.32 \pm 0.03$ & $1.83 \pm 0.02$ & $0.29 \pm 0.03$ & 261.88 & 23.1 & 0.89 \\
\hline R5 & Andesite & $2.91 \pm 0.03$ & $0.55 \pm 0.03$ & $1.49 \pm 0.02$ & $0.27 \pm 0.03$ & $1.48 \pm 0.02$ & $0.25 \pm 0.02$ & 166.81 & 16.24 & 0.9 \\
\hline R6 & Andesite & $3.71 \pm 0.03$ & $0.74 \pm 0.02$ & $1.94 \pm 0.02$ & $0.32 \pm 0.02$ & $1.83 \pm 0.02$ & $0.29 \pm 0.03$ & 260.44 & 22.6 & 0.84 \\
\hline R7 & Trachyte & $3.93 \pm 0.02$ & $0.79 \pm 0.02$ & $2 \pm 0.03$ & $0.33 \pm 0.03$ & $1.94 \pm 0.03$ & $0.31 \pm 0.03$ & 208.78 & 15.7 & 0.88 \\
\hline $\mathrm{R} 8$ & Latite & $4.26 \pm 0.04$ & $0.74 \pm 0.02$ & $1.77 \pm 0.02$ & $0.29 \pm 0.02$ & $1.48 \pm 0.02$ & $0.24 \pm 0.02$ & 290.05 & 25 & 0.84 \\
\hline R9 & $\begin{array}{l}\text { Nepheline } \\
\text { latite }\end{array}$ & $2.04 \pm 0.04$ & $0.38 \pm 0.02$ & $0.92 \pm 0.03$ & $0.14 \pm 0.002$ & $0.76 \pm 0.02$ & $0.11 \pm 0.002$ & 146.37 & 33.9 & 0.95 \\
\hline $\mathrm{R} 10$ & Basalt & $5.06 \pm 0.02$ & $0.92 \pm 0.03$ & $2.21 \pm 0.03$ & $0.33 \pm 0.002$ & $1.83 \pm 0.02$ & $0.26 \pm 0.001$ & 413.28 & 39.6 & 0.96 \\
\hline R11 & Basalt & $5.07 \pm 0.03$ & $0.86 \pm 0.02$ & $2.05 \pm 0.02$ & $0.3 \pm 0.002$ & $1.5 \pm 0.03$ & $0.22 \pm 0.001$ & 562.85 & 60.9 & 0.97 \\
\hline $\mathrm{R} 12$ & Travertine & $0.16 \pm 0.02$ & $0.04 \pm 0.001$ & $0.11 \pm 0.02$ & $0.04 \pm 0.001$ & $0.09 \pm 0.003$ & $0.02 \pm 0.001$ & 6.31 & 6.9 & 0.91 \\
\hline $\mathrm{R} 13$ & Travertine & $0.02 \pm 0.001$ & $0.02 \pm 0.001$ & $0.04 \pm 0.001$ & $0.04 \pm 0.001$ & $0.04 \pm 0.001$ & $0.02 \pm 0.001$ & 0.26 & 0.45 & 1.95 \\
\hline R14 & Travertine & $0.12 \pm 0.02$ & $0.03 \pm 0.001$ & $0.11 \pm 0.02$ & $0.04 \pm 0.001$ & $0.08 \pm 0.001$ & $0.03 \pm 0.001$ & 5.26 & 4.06 & 0.88 \\
\hline $\mathrm{R} 15$ & Travertine & $0.06 \pm 0.001$ & $0.02 \pm 0.001$ & $0.04 \pm 0.001$ & $0.04 \pm 0.001$ & $0.04 \pm 0.001$ & $0.02 \pm 0.001$ & 3.15 & 4.2 & 0.8 \\
\hline R16 & Travertine & $0.1 \pm 0.001$ & $0.03 \pm 0.001$ & $0.08 \pm 0.001$ & $0.04 \pm 0.001$ & $0.07 \pm 0.001$ & $0.02 \pm 0.001$ & 4.8 & 5.6 & 0.47 \\
\hline
\end{tabular}

The highest As concentration was measured in travertine samples, probably due to the presence of Aragonite in their mineralogy. This mineral is a calcium carbonate polymorph, and arsenic can 
reside in $\mathrm{Ca}$ layers perpendicular to the $\mathrm{C}$ axis. Substitution of calcium by arsenic generally occurs only in aragonite crystal structure (Pentecost 2005). Travertines rich in As (and also Sb) are commonly known as hydrothermal travertines (Bernasconi et al. 1980). The mean As concentrations of the intermediate rocks, basic rocks, and travertines were 614, 7.3 and 7994 $\mathrm{mg} / \mathrm{kg}$, respectively, indicating the greater role of felsic rocks in hydrothermal formation of travertines in the study area. The highest As concentration $(5140 \mathrm{mg} / \mathrm{kg})$ of the volcanic rock samples was observed in a latite, sampled around Babagorgor Spring (Table 1).

Geochemistry of REEs is a powerful tool for assessing magmatic processes, partial melting or magma mixing and crystal fractionation (Jones et al. 1995). The results of this study showed relatively high $\sum$ REEs concentration $(146-401 \mathrm{mg} / \mathrm{kg})$, REEs' dissociation coefficient $[(\mathrm{La} / \mathrm{Lu}) \mathrm{N}]$ of 15.7-33.9, and positive anomaly of Eu (0.84-0.95) for volcanic rocks, except basalt samples, indicating intermediate to felsic rock composition (Henderson 2013). The Eu anomaly in felsicintermediate magmas is controlled by feldspars. Contrary to other rare earth elements (with trivalent oxidation state), Eu could also have a divalent oxidation state and commonly enters the plagioclase and K-feldspar structures as a compatible element. Therefore, the occurrence of primary feldspars, or their formation in the late stages of differentiation have resulted in a positive anomaly of $\mathrm{Eu}$ in volcanic rocks of the area, a feature characteristic of continental margins and their related magmatism (Henderson 2013). The mean $\sum$ REEs concentration, REEs' dissociation

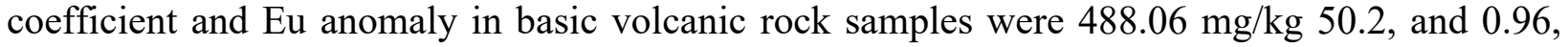
respectively (Table 1). Based on Henderson (1989), $\sum$ REEs and Eu anomaly of basic rocks range from $25-150 \mathrm{mg} / \mathrm{kg}$ and $0.01-0.05$, respectively. The higher values observed in basic rocks of this study may reflect the mixing of these rocks with felsic magma. This magma may have lost its As due to rapid oxidation.

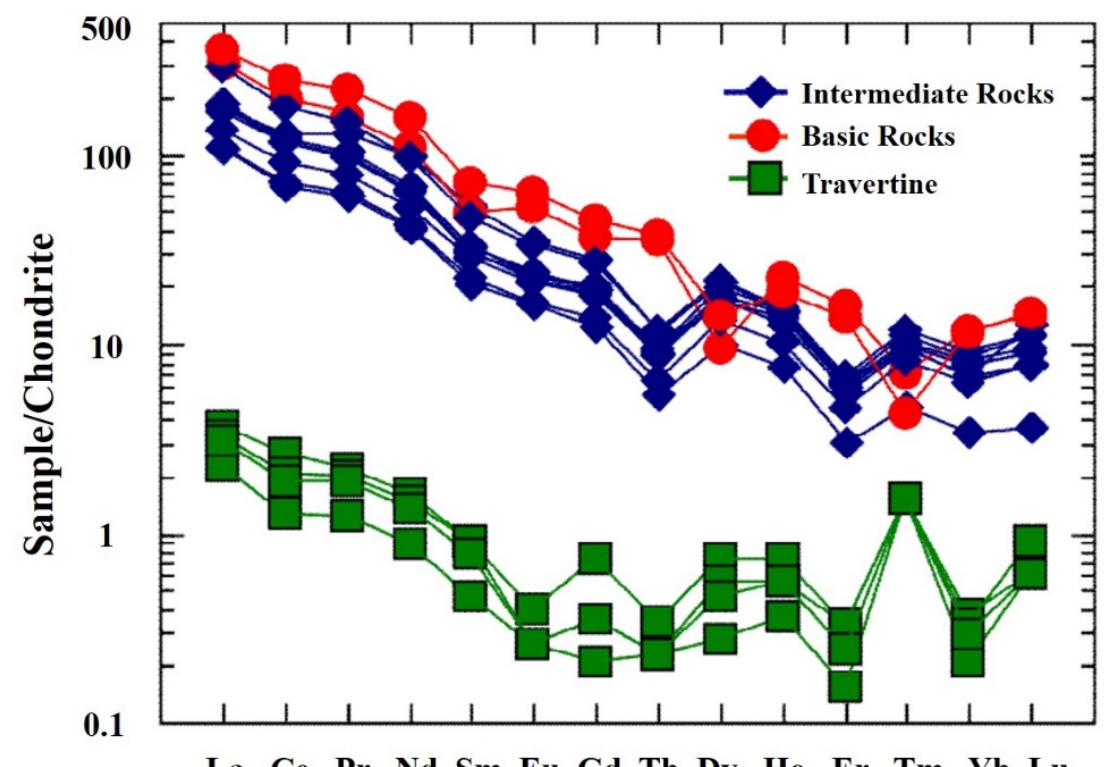

La Ce Pr Nd Sm Eu Gd Tb Dy Ho Er Tm Yb Lu

Figure 2. REEs pattern in the volcanic rocks of the study area, normalized by composite chondrite (Wakita et al. 1971). 
Hydrothermal travertines in the study area showed a relatively similar REEs pattern with the intermediate volcanoes (Fig 2). However, $\sum$ REEs concentrations in travertines in this study, with an average of $3.9 \mathrm{mg} / \mathrm{kg}$ are significantly $(\mathrm{p}<0.05)$ lower than those for volcanic rock samples, while $\mathrm{Eu}$ anomaly increases and the ratio of dissociation degree (average $=4.2$ ) decreases significantly. Lower $\sum$ REEs concentrations in travertines is related to the post-depositional mobilization of these elements. Figure 2 shows that heavy rare earth elements (HREEs) including $\mathrm{Eu}, \mathrm{Gd}, \mathrm{Tb}, \mathrm{Dy}, \mathrm{Ho}, \mathrm{Er}, \mathrm{Tm}, \mathrm{Yb}$ and Lu were more depleted during travertine deposition. REEs differentiation in carbonate rocks depends highly on physicochemical conditions of the initial environment, diagenesis and metamorphism, composition of secondary hydrothermal fluids, and mineralogy (Bao et al. 2004). During rock-fluids inter-reactions, light rare earth elements (LREEs) including $\mathrm{La}, \mathrm{Ce}, \mathrm{Pr}, \mathrm{Nd}$ and $\mathrm{Sm}$ will be leached more readily. This is a specific feature of carbonate rocks coming into contact with hydrothermal fluids (Lottermoser 1992). On the other hand, differences in the ionic radius of $\mathrm{Mg}^{2+}, \mathrm{Ca}^{2+}, \mathrm{Fe}^{2+}$ and $\mathrm{REEs}^{3+}$ may also be responsible for the exclusion of LREEs from calcite and dolomite crystallographic structures (Fernández-Nieto et al. 2003).

\subsection{Soil and plants pollution}

Total soil As concentrations are presented in Table 2 with concentrations ranging from 7.7 to 429.5 $\mathrm{mg} / \mathrm{kg}$. Mean concentration of As in the study area soils $(66.76 \mathrm{mg} / \mathrm{kg})$ was much higher than the maximum acceptable limit for agricultural soil recommended by the European Community (20 $\mathrm{mg} / \mathrm{kg}$ ) (Rahman et al. 2007). Also, there is a large difference between soil mean As concentration in Qorveh and Bijar being 48.5 and $106.6 \mathrm{mg} / \mathrm{kg}$, respectively (Table 2). This difference probably reflects different geogenic and hydrothermal processes, since in this belt, magmatic differentiation and ratio of acidic/intermediate rocks increases from Qorveh towards Bijar. In many parts of the world, release of geogenic As is associated with Tertiary volcanic activity and the resulting formation of volcanic ashes, hydrothermal springs and other related geothermal features (Bundschuh et al. 2007).

Table 2. Summary statistics of arsenic concentration ( \pm SD) in soils and crops.

\begin{tabular}{|c|c|c|c|c|c|c|}
\hline \multirow{2}{*}{ Arsenic } & \multicolumn{3}{|c|}{ Soil (mg/kg) } & \multirow{2}{*}{$\begin{array}{l}\text { Wheat } \\
(\mu \mathrm{g} / \mathrm{kg})\end{array}$} & \multirow{2}{*}{$\begin{array}{l}\text { Barley } \\
(\mu \mathrm{g} / \mathrm{kg})\end{array}$} & \multirow{2}{*}{ Alfalfa $(\mu \mathrm{g} / \mathrm{kg})$} \\
\hline & Whole area & Qorveh & Bijar & & & \\
\hline $\begin{array}{l}\text { Limit of } \\
\text { detection }\end{array}$ & \multicolumn{3}{|c|}{0.5} & \multicolumn{3}{|c|}{50} \\
\hline Mean & $66.73 \pm 0.6$ & $48.5 \pm 0.5$ & $106.62 \pm 0.8$ & $107.95 \pm 0.6$ & $348.67 \pm 1$ & $3911.81 \pm 2$ \\
\hline Median & $45 \pm 0.6$ & $38 \pm 0.5$ & $60.2 \pm 0.5$ & $62 \pm 0.5$ & $176 \pm 1$ & $1281 \pm 1$ \\
\hline Std. Deviation & 81.58 & 37.55 & 128.49 & 94.21 & 418.47 & 6437.16 \\
\hline Skewness & 3.01 & 1.79 & 1.7 & 1.72 & 2.21 & 3.12 \\
\hline Min & $7.7 \pm 0.15$ & $7.7 \pm 0.15$ & $11 \pm 0.2$ & $<50$ & $<50$ & 71 \\
\hline Max & $429.5 \pm 0.9$ & $187.2 \pm 0.5$ & $429.5 \pm 0.9$ & $429 \pm 0.9$ & $1633 \pm 3$ & $25079 \pm 2$ \\
\hline $\begin{array}{l}\text { Maximum } \\
\text { acceptable } \\
\text { concentration }\end{array}$ & \multicolumn{3}{|c|}{$20^{\mathrm{a}}$} & & $1000^{\mathrm{b}}$ & \\
\hline
\end{tabular}


In order to investigate the relationship between the major rock outcrops of the study area and adjacent soils, mean As concentrations in the four rock types (basalt, andesite, latite and travertine) and 18 surrounded fields where the rock and soil samples are in close proximity were considered (Fig 3). As shown in the diagram, the soil samples adjacent to travertine outcrops have the highest As concentration, which corresponds to the high concentration of this element in travertine compared to other rock types. Also, the results of Kruskal-Wallis H test (Table 3) showed a significant difference $(p<0.05)$ in As concentration of soils around travertine outcrops (with highest mean rank) and other rock types. On the other hand, lower soil As concentration around Dashakasan Gold Mine (maximum of $187 \mathrm{mg} / \mathrm{kg}$ ) in Southeast of the study area, relative to areas with no gold mineralization (such as Aliabad with $429.5 \mathrm{mg} \mathrm{As} / \mathrm{kg}$ ) in North of the study area reveals that in comparison with gold mineralization and mining activities, hydrothermal processes play a more important role in soil arsenic enrichment. As discussed earlier, hydrothermal travertines are rich in arsenic, and its weathering could in turn produce As-rich soils. It should be noted that most of the agricultural fields in the area are associated with travertine outcrops. In Qorveh-Bijar region, deep groundwater circulation is responsible for high As pollution of water resources, and As concentrations ranging from 0.4 to 688.9 , and 212 to $842.3 \mu \mathrm{g} / \mathrm{L}$ were reported in groundwater and travertine springs, respectively. These high concentrations coincide to areas with the highest arsenic concentrations in the soil samples (Keshavarzi et al. 2011). Therefore, using groundwater and travertine springs for irrigation purposes particularly for vegetable crops (Sharifi et al. 2017) and alfalfa (one field in this study) will subsequently cause further arsenic enrichment in agricultural soils, and the use of such waters for irrigation could be considered as an important As source in croplands.

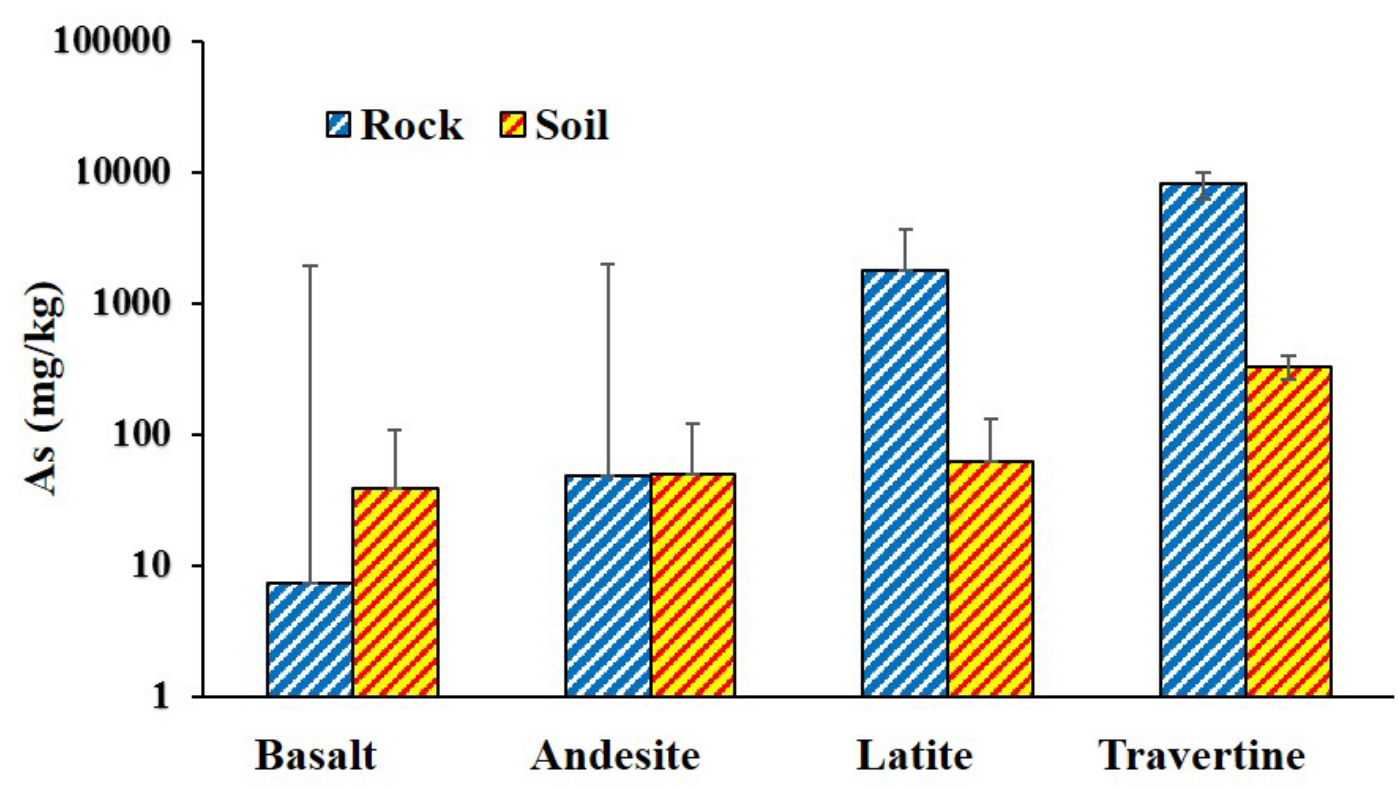

Figure 3. Comparison of mean As concentration ( \pm standard error) in the soil and rock study samples.

Pollution index (PI) and index of geoaccumulation (Igeo) are two useful means of evaluating the degree of soil pollution (Fig 4). Results showed that calculated PI ranges from 0.64 to 35.79 with 
the highest values occurring in Aliabad village soil in Bijar County. According to pollution index classification (Yang et al. 2011), 50\% and 34\% of the soil samples must be categorized as highly polluted (PI $>5)$ in Bijar and Qorveh, respectively. Also, minimum, maximum and mean value of

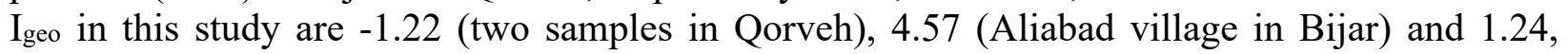
respectively. Only $17.64 \%$ of the soil samples were classified as unpolluted, and the highest proportion (i.e. $35.3 \%$ of the samples) was classified as "moderately polluted". Moreover, $25.49 \%$, $13.72 \%, 1.97 \%$ and $5.88 \%$ of the soil samples were categorized as unpolluted to moderately polluted, moderately to strongly polluted, strongly polluted, and strongly to extremely polluted, respectively (Fig 4).

Table 3. Kruskal-Wallis H test for As in soils around different rock types.

\begin{tabular}{ccccc|ccc}
\hline Group & Basalt & Andesite & Latite & Travertine & Chi-Square & df & Asymp. Sig. \\
\hline Mean Rank & 7.67 & 7.6 & 13.5 & 19 & 10.31 & 3 & 0.016 \\
\hline
\end{tabular}
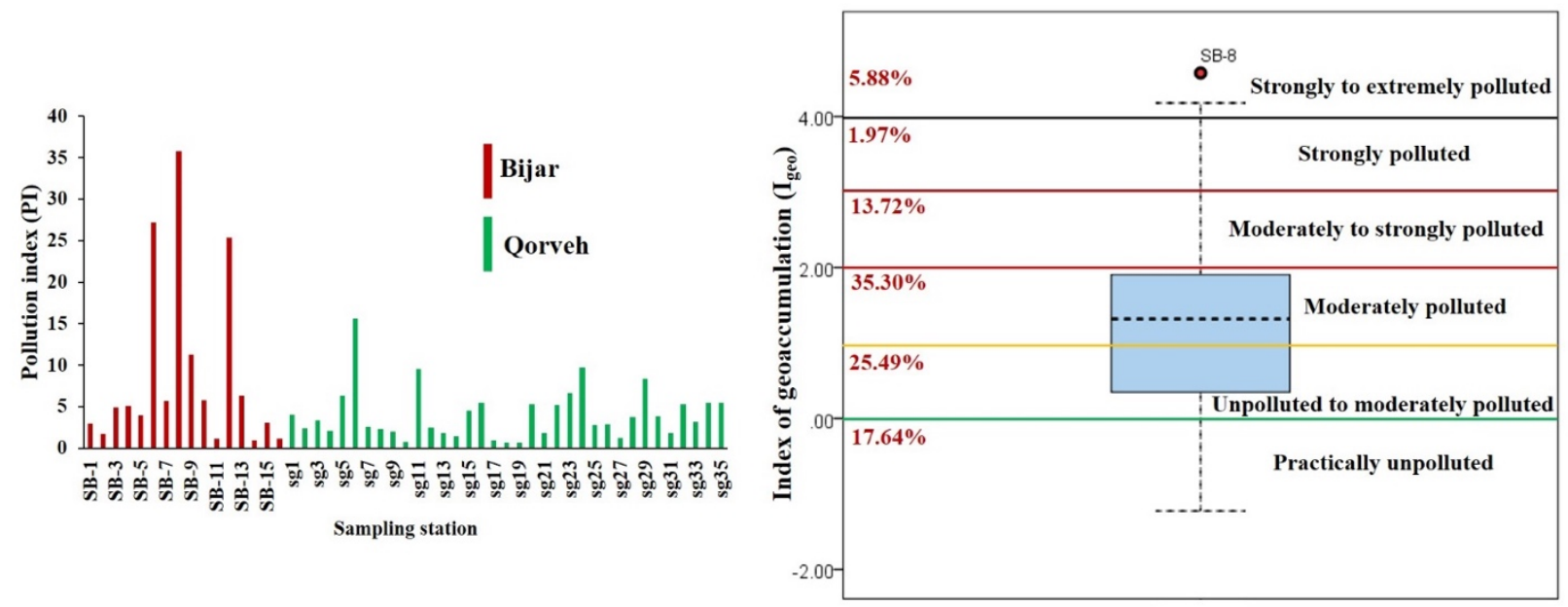

Figure 4. PI bar graph and $\mathrm{I}_{\text {geo }}$ boxplot for arsenic in soil samples.

Arsenic concentrations in wheat, barley and alfalfa ranged from $<50$ to $429 \mu \mathrm{g} / \mathrm{kg} \mathrm{dw}$ (mean; $107.95 \mu \mathrm{g} / \mathrm{kg} \mathrm{dw}$ ), $<50$ to $1633 \mu \mathrm{g} / \mathrm{kg} \mathrm{dw}$ (mean; $348.67 \mu \mathrm{g} / \mathrm{kg} \mathrm{dw}$ ), and 71 to $25079 \mu \mathrm{g} / \mathrm{kg} \mathrm{dw}$ (mean; $3911.81 \mu \mathrm{g} / \mathrm{kg} \mathrm{dw}$ ), respectively. The highest concentrations in the three analyzed crop plants were found in Gilaklou, Ebrahimabad and Babagorgor villages, for wheat, barley and alfalfa, respectively. The farm from which alfalfa samples were collected at Babagorgor village is the only arable land directly irrigated with travertine spring in which, $80 \%$ of the arsenic was available in trivalent state (Keshavarzi 2011), resulting in high As content in alfalfa. Compared 
with maximum permissible concentration (MPC) for foodstuffs, average As content in the plant samples were higher with concentrations above MPC being measured in one barley and 11 alfalfa samples. Mann-Whitney U test was used to examine the statistical significance of the differences in As content among three sampled crop species, and the two counties (Table 4). The results revealed significant differences between As concentration in different plant species ( $p<0.001$ to 0.021), reflecting the following trend for As concentration: alfalfa stem and leaves $>$ barley grains $>$ wheat grains. Irrigation of alfalfa fields by As contaminated groundwater may be an important factor, elevating concentrations of arsenic in alfalfa compared to rainfed wheat and barley. However, no significant difference was found between Bijar and Qorveh Counties in regard to As in plants $(\mathrm{p}=0.100)$.

Table 4. Mann-Whitney U test for As between the plant species, and studied counties.

\begin{tabular}{ccccc}
\hline & Wheat-Barley & Wheat-Alfalfa & Barley-Alfalfa & Bijar-Qorveh \\
\hline Mann-Whitney U & 123 & 14 & 26 & 272 \\
Wilcoxon W & 529 & 420 & 162 & 1052 \\
Z & -2.514 & -4.913 & -3.577 & -1.646 \\
$\begin{array}{c}\text { Asymp. Sig. (2- } \\
\text { tailed) }\end{array}$ & 0.012 & 0.000 & 0.000 & 0.100 \\
\hline
\end{tabular}
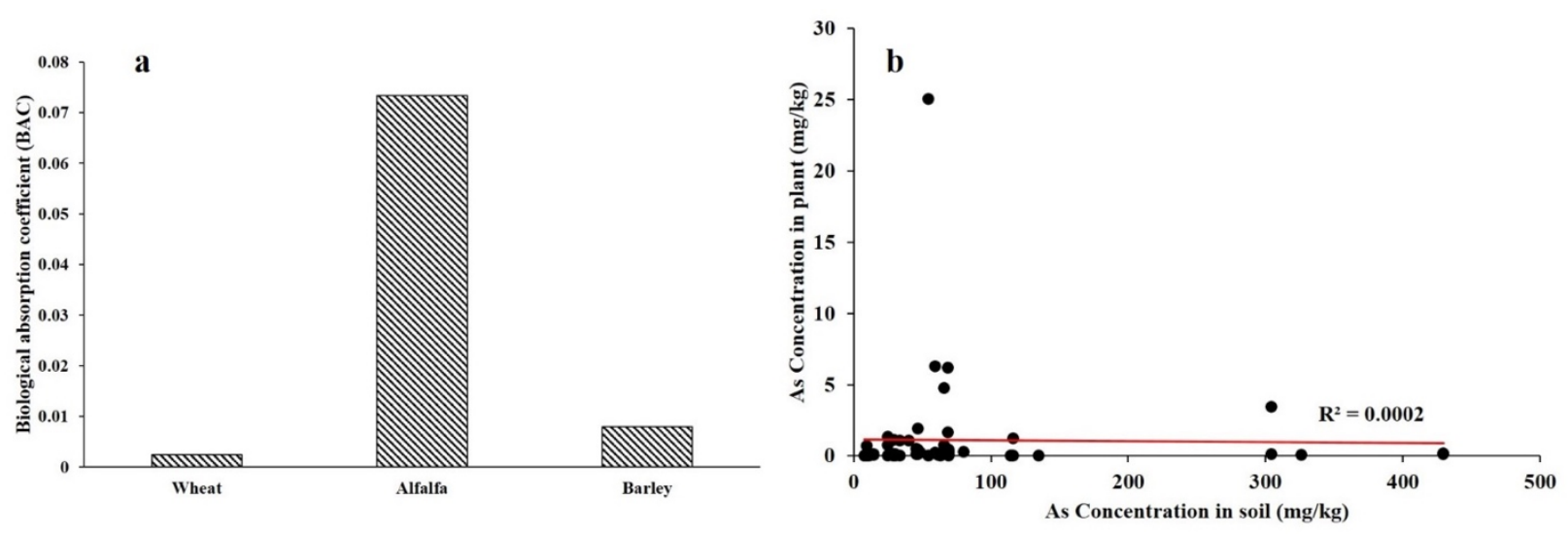

Figure 5. (a) Mean Biological absorption coefficient and (b) relationship between As contents of the study soil and crop plants.

Biological absorption coefficient (BAC) was calculated to examine the transfer of As from soil to plant (Fig 5a). The BAC values differed across the three crop plants, indicating the importance of plant species on arsenic accumulation in the crop's edible parts. Alfalfa showed the highest BAC among the studied plants, which is in accordance with other reported data that leafy plants/vegetables accumulate higher arsenic than cereal grains (Alam et al. 2003; Samal 2005; 
Sharifi et al. 2017). As mentioned earlier, irrigation of alfalfa fields by groundwater is a likely contributor to greater uptake of As by this crop. The relationship between soil and crop plants (Fig $5 b)$ indicates that there is no significant correlation between the concentration of As in soil and crops. This is hardly surprising as total soil arsenic concentration is not the sole factor controlling its bioavailability. As reported in other works, soil properties including soil organic matter (SOM), sulphate $\left(\mathrm{SO}_{4}{ }^{2-}\right)$, soil texture, phosphate $\left(\mathrm{PO}_{4}{ }^{3-}\right)$, silica, nitrate $\left(\mathrm{NO}_{3}{ }^{-}\right)$, As speciation etc., may also affect arsenic bioavailability for plants (Huang et al. 2006; Zhao et al. 2009; Keshavarzi et al. 2015b; Yu et al. 2016; Sharma et al. 2020).

\subsection{Health risk assessment}

Table 5. The calculated values of CDI, HQ and ILTCR for wheat and barley.

\begin{tabular}{llcccccc}
\hline \multirow{2}{*}{ County } & \multirow{2}{*}{ Species } & \multicolumn{2}{c}{ CDI } & \multicolumn{2}{c}{ HQ } & \multicolumn{2}{c}{ ILTCR } \\
\cline { 3 - 8 } Qorveh & & Adults & Children & Adults & Children & Adults & Children \\
& Wheat & $7.05 \mathrm{E}-04$ & $2.47 \mathrm{E}-03$ & 2.35 & 8.23 & $1.30 \mathrm{E}-04$ & $1.37 \mathrm{E}-03$ \\
& Barley & $7.53 \mathrm{E}-04$ & $2.64 \mathrm{E}-03$ & 2.51 & 8.79 & $1.61 \mathrm{E}-04$ & $1.69 \mathrm{E}-03$ \\
\multirow{2}{*}{ Bijar } & Wheat & $9.25 \mathrm{E}-04$ & $3.24 \mathrm{E}-03$ & 3.08 & 10.79 & $1.69 \mathrm{E}-04$ & $1.77 \mathrm{E}-03$ \\
& Barley & $1.42 \mathrm{E}-03$ & $4.96 \mathrm{E}-03$ & 4.72 & 16.53 & $4.58 \mathrm{E}-04$ & $4.80 \mathrm{E}-03$ \\
\hline
\end{tabular}

The results of chronic daily intake (CDI), hazard quotient (HQ) and incremental lifetime cancer risk (ILTCR) are summarized in Table 5, showing relatively high CDI values for both children and adults particularly in Bijar. Compared with tolerable intake level of $3 \mu \mathrm{g}$ As $/ \mathrm{kg}$ body weight per day (WHO 2011), As in Bijar County displayed higher CDI values. On the other hand, the HQ exceeds unity for both adults and children, indicating that potential non-cancer effects from the cereal consumption should be considered a concern, particularly for barley. Also, due to their smaller bodyweight and consequently higher values of the indices, children are at higher risk in comparison with adults. Moreover, the calculated ILTCR values were $1.3 \times 10^{-4}$ to $4.58 \times 10^{-4}$, and $1.37 \times 10^{-3}$ to $4.80 \times 10^{-3}$ for adults and children, respectively. The higher ILTCR values for children suggest that they are at greater risk of cancer than adults. Due to higher As concentration, barley grain displayed a higher cancer risk compared with wheat grains, and consumption of crops cultivated in Bijar may pose greater cancer risk. The total carcinogenic risk of As was significantly higher than the acceptable limit $\left(10^{-4}\right)$ for both adults and children in the study area, so action should be taken to reduce the exposure and cancer risk. The health risk of As from ingestion route (food crops and water) has also been examined in several other studies (Huang et al. 2008; Sharifi et al. 2017; Wen et al. 2019; Kaur et al. 2019). It should be noted that while alfalfa was not considered in human health risk assessment, it could affect both livestock (directly) and human (indirectly) because of its high As content in the study area. Injury to hepatocytes, other liver damages and anemia in sheep are already reported in the study area by Keshavarzi et al. (2015a). 


\section{Conclusion}

The investigation of arsenic distribution in rocks, soils and three crops in affected Qorveh and Bijar counties, as part of Sanandaj-Sirjan magmatic-metamorphic belt demonstrated geogenic origin of arsenic in the area. In view of REEs behavior in rocks and their relationship with As revealed the role of intermediate volcanic rocks especially travertine in increasing As content in the region. Weathering of these high As-bearing rocks, resulted from waning stages of TertiaryQuaternary volcanic activity, at least partly contributed to As in agricultural soils. This together with irrigating arable lands with groundwater and travertine springs enriched in As seems to have caused severe contamination of the agricultural soils. Therefore, high arsenic content of crop samples in this area seems to have resulted from arsenic mobility and its transfer from rock-soil to plants which may pose high non-cancer and cancer risks for the inhabitants of this region. In recent years, alternative drinking water resources with low As content were supplied to mitigate the potential negative health effects in the population centers of Kurdistan Province, but as the results of this study show, ingestion of cultivated crops in this area also poses a high health risk for consumers. Furthermore, livestock in this area ingest As contaminated forage, along with polluted water, which provide an important indirect pathway for human exposure to arsenic. Reducing the negative health effects of arsenic to near zero, requires an efficient management programme in which all possible exposure pathways are taken into account.

\section{Acknowledgements}

The authors wish to express their gratitude to the Research Committee and Medical Geology Research Center of Shiraz University for logistic and technical assistance.

\section{Declaration of interests}

The authors declare that they have no known competing financial interests or personal relationships that could have appeared to influence the work reported in this paper 


\section{References}

Adamo, P., Iavazzo, P., Albanese, S., Agrelli, D., De Vivo, B., \& Lima, A. (2014). Bioavailability and soil-to-plant transfer factors as indicators of potentially toxic element contamination in agricultural soils. Science of the Total Environment, 500, 11-22.

Adriano, D. C. (2001). Trace elements in terrestrial environments, biogeochemistry, bioavailability and risks of metals. New York: Springer.

Ahmed, K. M., Imam, M. B., Akhter, S. H., Hasan, M. A., \& Khan, A. A. (2001). Sedimentology and mineralogy of arsenic contaminated aquifers in the Bengal Delta of Bangladesh. In Groundwater arsenic contamination in the Bengal Delta Plain of Bangladesh. Proc. KTH-Dhaka University Seminar. KTH Spec. Publ., TRITA-AMI Report (Vol. 3084, pp. 97108).

Alam, M. G. M., Snow, E. T., \& Tanaka, A. (2003). Arsenic and heavy metal contamination of vegetables grown in Samta village, Bangladesh. Science of the Total Environment, 308(13), 83-96.

Amjadian, K., Pirouei, M., Mehr, M. R., Shakeri, A., Rasool, S. K., \& Haji, D. I. (2018). Contamination, health risk, mineralogical and morphological status of street dusts-case study: Erbil metropolis, Kurdistan Region-Iraq. Environmental Pollution, 243, 1568-1578.

Amjadian, K., Pirouei, M., Mehr, M. R., Shakeri, A., Rasool, S. K., \& Haji, D. I. (2018). Contamination, health risk, mineralogical and morphological status of street dusts-case study: Erbil metropolis, Kurdistan Region-Iraq. Environmental Pollution, 243, 1568-1578.

Bao, Z., Zhao, Z., Guha, J., \& Williams, A. E. (2004). HFSE, REE, and PGE geochemistry of three sedimentary rock-hosted disseminated gold deposits in southwestern Guizhou Province, China. Geochemical Journal, 38(4), 363-381.

Barati, A. H., Maleki, A., \& Alasvand, M. (2010). Multi-trace elements level in drinking water and the prevalence of multi-chronic arsenical poisoning in residents in the west area of Iran. Science of the Total Environment, 408(7), 1523-1529.

Bernasconi, A., Glover, N., \& Viljoen, R. P. (1980). The geology and geochemistry of the senator antimony deposit-Turkey. Mineralium Deposita, 15(3), 259-274.

Bhattacharya, P., Samal, A. C., Majumdar, J., \& Santra, S. C. (2010). Arsenic contamination in rice, wheat, pulses, and vegetables: a study in an arsenic affected area of West Bengal, India. Water, Air, \& Soil Pollution, 213(1-4), 3-13.

Bhattacharya, P., Welch, A. H., Stollenwerk, K. G., McLaughlin, M. J., Bundschuh, J., \& Panaullah, G. (2007). Arsenic in the environment: biology and chemistry.

Boni, M., Gilg, H. A., Balassone, G., Schneider, J., Allen, C. R., \& Moore, F. (2007). Hypogene Zn carbonate ores in the Angouran deposit, NW Iran. Mineralium Deposita, 42(8), 799-820.

Bundschuh, J., García, M. E., Birkle, P., Cumbal, L., Bhattacharya, P., \& Matschullat, J. (2007). Groundwater arsenic in rural Latin America-Occurrence, Health effects and remediation experiences. Natural Arsenic in Groundwater of Latin America-Occurrence, Health impact and Remediation. AA Balkema Publisher, The Netherlands.

Canadian Council of Ministers of the Environment (CCME) (2007). Canadian soil quality guidelines for the protection of environmental and human health. Canadian Council of Minister of the Environment.

Chen, Y., Huang, B., Hu, W., Weindorf, D. C., Liu, X., \& Niedermann, S. (2014). Assessing the risks of trace elements in environmental materials under selected greenhouse vegetable production systems of China. Science of the Total Environment, 470, 1140-1150. 
Conklin, A. R. (2013). Introduction to soil chemistry: Analysis and instrumentation. John Wiley $\&$ Sons.

Dradrach, A., Karczewska, A., \& Szopka, K. (2020). Arsenic accumulation by red fescue (Festuca rubra) growing in mine affected soils-Findings from the field and greenhouse studies. Chemosphere, 248, 126045.

Edwards, S. C., MacLeod, C. L., \& Lester, J. N. (1998). The bioavailability of copper and mercury to the common nettle (Urtica dioica) and the earthworm Eisenia fetida from contaminated dredge spoil. Water, Air, and Soil Pollution, 102(1-2), 75-90.

Farooq, S. H., Chandrasekharam, D., Dhanachandra, W., \& Ram, K. (2019). Relationship of arsenic accumulation with irrigation practices and crop type in agriculture soils of Bengal Delta, India. Applied Water Science, 9(5), 119.

Fernández-Nieto, C., Torres-Ruiz, J., Subías Pérez, I., Fanlo González, I., \& González López, J. M. (2003). Genesis of Mg-Fe carbonates from the Sierra Menera magnesite-siderite deposits, Northeast Spain: evidence from fluid inclusions, trace elements, rare earth elements, and stable isotope data. Economic Geology, 98(7), 1413-1426.

Ghezeljeh, E. A., Mesgaran, D. M., Moghaddam, N. H., \& Vakili, A. (2011). Bulk density, chemical composition and in vitro gas production parameters of Iranian barley grain cultivars grown at different selected climates. African Journal of Agricultural Research, 6(5), 12261232.

Halder, D., Biswas, A., Šlejkovec, Z., Chatterjee, D., Nriagu, J., Jacks, G., \& Bhattacharya, P. (2014). Arsenic species in raw and cooked rice: Implications for human health in rural Bengal. Science of the Total Environment, 497, 200-208.

Henderson, P. (Ed.). (2013). Rare earth element geochemistry (Vol. 2). Elsevier.

Hossain, M. F. (2006). Arsenic contamination in Bangladesh-an overview. Agriculture, Ecosystems \& Environment, 113(1-4), 1-16.

Hu, Y., Liu, X., Bai, J., Shih, K., Zeng, E. Y., \& Cheng, H. (2013). Assessing heavy metal pollution in the surface soils of a region that had undergone three decades of intense industrialization and urbanization. Environmental Science and Pollution Research, 20(9), 6150-6159.

Huang, M., Zhou, S., Sun, B., \& Zhao, Q. (2008). Heavy metals in wheat grain: assessment of potential health risk for inhabitants in Kunshan, China. Science of the Total Environment, 405(1-3), 54-61.

Huang, R. Q., Gao, S. F., Wang, W. L., Staunton, S., \& Wang, G. (2006). Soil arsenic availability and the transfer of soil arsenic to crops in suburban areas in Fujian Province, southeast China. Science of the Total Environment, 368(2-3), 531-541.

Jones, A. P., Wall, F., \& Williams, C. T. (1995). Rare earth minerals: chemistry, origin and ore deposits (Vol. 7). Springer Science \& Business Media.

Kabata-Pendias, A., \& Mukherjee, A. B. (2007). Trace elements from soil to human. Springer Science \& Business Media.

Karimi, A., Ahmadi, A., \& Partabian, A. (2019). Potential soil pollution by heavy metals in Kurdistan region, western Iran: the impact of ultramafic bedrock. Geopersia.

Kaur, G., Kumar, R., Mittal, S., Sahoo, P. K., \& Vaid, U. (2019). Ground/drinking water contaminants and cancer incidence: A case study of rural areas of South West Punjab, India. Human and Ecological Risk Assessment: An International Journal, 1-22.

Keshavarzi, B. (2011). Medical geology and the source of arsenic in northern sanandaj-sirjan magmatic-metamorphic belt. Ph. D dissertation, Shiraz University. 
Keshavarzi, B., Moore, F., Ansari, M., Mehr, M. R., Kaabi, H., \& Kermani, M. (2015b). Macronutrients and trace metals in soil and food crops of Isfahan Province, Iran. Environmental monitoring and assessment, 187(1), 4113.

Keshavarzi, B., Moore, F., Mosaferi, M., \& Rahmani, F. (2011). The source of natural arsenic contamination in groundwater, west of Iran. Water Quality, Exposure and Health, 3(3-4), 135-147.

Keshavarzi, B., Seradj, A., Akbari, Z., Moore, F., Shahraki, A. R., \& Pourjafar, M. (2015a). Chronic arsenic toxicity in sheep of Kurdistan province, western Iran. Archives of environmental contamination and toxicology, 69(1), 44-53.

Kundu, M., Ghosh, P., Mitra, S., Das, J. K., Sau, T. J., Banerjee, S., \& Giri, A. K. (2011). Precancerous and non-cancer disease endpoints of chronic arsenic exposure: the level of chromosomal damage and XRCC3 T241M polymorphism. Mutation Research/Fundamental and Molecular Mechanisms of Mutagenesis, 706(1), 7-12.

Lee, J. S., Lee, S. W., Chon, H. T., \& Kim, K. W. (2008). Evaluation of human exposure to arsenic due to rice ingestion in the vicinity of abandoned Myungbong $\mathrm{Au}-\mathrm{Ag}$ mine site, Korea. Journal of Geochemical Exploration, 96(2-3), 231-235.

Liu, C. P., Luo, C. L., Gao, Y., Li, F. B., Lin, L. W., Wu, C. A., \& Li, X. D. (2010). Arsenic contamination and potential health risk implications at an abandoned tungsten mine, southern China. Environmental Pollution, 158(3), 820-826.

Lottermoser, B. G. (1992). Rare earth elements and hydrothermal ore formation processes. Ore Geology Reviews, 7(1), 25-41.

Martin, M., Bonifacio, E., Hossain, K. J., Huq, S. I., \& Barberis, E. (2014). Arsenic fixation and mobilization in the soils of the Ganges and Meghna floodplains. Impact of pedoenvironmental properties. Geoderma, 228, 132-141.

Mathee, A., Kootbodien, T., Kapwata, T., \& Naicker, N. (2018). Concentrations of arsenic and lead in residential garden soil from four Johannesburg neighborhoods. Environmental research, 167, 524-527.

Mosaferi, M., Yunesian, M., Dastgiri, S., Mesdaghinia, A., \& Esmailnasab, N. (2008). Prevalence of skin lesions and exposure to arsenic in drinking water in Iran. Science of the total environment, 390(1), 69-76.

Mukherjee, A., Sengupta, M. K., Hossain, M. A., Ahamed, S., Das, B., Nayak, B., ... \& Chakraborti, D. (2006). Arsenic contamination in groundwater: a global perspective with emphasis on the Asian scenario. Journal of Health, Population and Nutrition, 142-163.

Myrvang, M. B., Gjengedal, E., Heim, M., Krogstad, T., \& Almås, Å. R. (2016). Geochemistry of barium in soils supplied with carbonatite rock powder and barium uptake to plants. Applied geochemistry, 75, 1-8.

Nasrabadi, T., \& Bidabadi, N. S. (2013). Evaluating the spatial distribution of quantitative risk and hazard level of arsenic exposure in groundwater, case study of Qorveh County, Kurdistan Iran. Iranian Journal of Environmental Health Science and Engineering, 10(1), 30.

National Food Authority. (1993). 'Australian Food Standard Code: March, 1993'. Australian Govt. Pub. Service, Canberra.

Nickson, R. T., McArthur, J. M., Shrestha, B., Kyaw-Myint, T. O., \& Lowry, D. (2005). Arsenic and other drinking water quality issues, Muzaffargarh District, Pakistan. Applied Geochemistry, 20(1), 55-68.

Ongley, L. K., Sherman, L., Armienta, A., \& Salinas, C. F. (2007). Arsenic in the soils of Zimapán, Mexico. Environmental pollution, 145(3), 793-799. 
Otones, V., Álvarez-Ayuso, E., García-Sánchez, A., Santa Regina, I., \& Murciego, A. (2011). Arsenic distribution in soils and plants of an arsenic impacted former mining area. Environmental pollution, 159(10), 2637-2647.

Pentecost, A. (2005). Travertine. Springer Science \& Business Media.

Pourreza, A., Pourreza, H., Abbaspour-Fard, M. H., \& Sadrnia, H. (2012). Identification of nine Iranian wheat seed varieties by textural analysis with image processing. Computers and electronics in agriculture, 83, 102-108.

Qing, X., Yutong, Z., \& Shenggao, L. (2015). Assessment of heavy metal pollution and human health risk in urban soils of steel industrial city (Anshan), Liaoning, Northeast China. Ecotoxicology and environmental safety, 120, 377-385.

Rahman, M. A., Hasegawa, H., Rahman, M. M., Rahman, M. A., \& Miah, M. A. M. (2007). Accumulation of arsenic in tissues of rice plant (Oryza sativa L.) and its distribution in fractions of rice grain. Chemosphere, 69(6), 942-948.

Rahman, M. M., Asaduzzaman, M., \& Naidu, R. (2011). Arsenic exposure from rice and water sources in the Noakhali district of Bangladesh. Water Quality, Exposure and Health, 3(1), $1-10$.

Rahman, M. M., Asaduzzaman, M., \& Naidu, R. (2013). Consumption of arsenic and other elements from vegetables and drinking water from an arsenic-contaminated area of Bangladesh. Journal of hazardous materials, 262, 1056-1063.

Rana, T., Bera, A. K., Bhattacharya, D., Das, S., Pan, D., \& Das, S. K. (2012). Chronic arsenicosis in goats with special reference to its exposure, excretion and deposition in an arsenic contaminated zone. Environmental toxicology and pharmacology, 33(2), 372-376.

Samal, A. C. (2005). An investigation on accumulation of arsenic in ecosystem of Gangetic West Bengal and assessment of potential health risk. Ph. D Thesis, University of Kalyani.

Sharifi, R., Moore, F., \& Keshavarzi, B. (2014). Potential health risks of arsenic, antimony and mercury in the Takab geothermal field, NW Iran. International Journal of Environmental Studies, 71(3), 372-390.

Sharifi, R., Moore, F., Keshavarzi, B., \& Badiei, S. (2017). Assessment of Health Risks of Arsenic Exposure via Consumption of Crops. Exposure and Health, 1-15.

Sharma, S., Kumar, R., Sahoo, P. K., \& Mittal, S. (2020). Geochemical relationship and translocation mechanism of arsenic in rice plants: A case study from health prone south west Punjab, India. Groundwater for Sustainable Development, 100333.

Smith, E., Weber, J., \& Juhasz, A. L. (2009). Arsenic distribution and bioaccessibility across particle fractions in historically contaminated soils. Environmental geochemistry and health, 31(1), 85-92.

States, J. C., Srivastava, S., Chen, Y., \& Barchowsky, A. (2008). Arsenic and cardiovascular disease. Toxicological sciences, 107(2), 312-323.

Tu, S., \& Ma, L. Q. (2003). Interactive effects of $\mathrm{pH}$, arsenic and phosphorus on uptake of As and $\mathrm{P}$ and growth of the arsenic hyperaccumulator Pteris vittata L. under hydroponic conditions. Environmental and Experimental Botany, 50(3), 243-251.

USEPA (U.S. Environmental Protection Agency) (1998). Integrated risk information system: arsenic, inorganic, CASRN 7440-38-2 Washington, DC.

USEPA (United States Environmental Protection Agency) (1989). Risk assessment guidance for superfund. Human Health Evaluation Manual (Part A). Interim Final, vol. I. Washington (DC): United States Environmental Protection Agency; EPA/540/1-89/002. 
USEPA (United States Environmental Protection Agency) (2000). Handbook for non-cancer health effects evaluation. Washington (DC): US Environmental Protection Agency.

USEPA (US Environmental Protection Agency) (2001). Supplemental guidance for developing soil screening levels for superfund sites. OSWER 9355.4-24.

USEPA (US Environmental Protection Agency). 2008. Atlas Asbestos Mine Superfund Site. Releases Exposure and Risk Assessment for Clear Creek Management Area. United States Environmental Protection Agency, Region 9, San Francisco, CA; [from: http://www.epa.gov/region9/toxic/noa/clearcreek/pdf/CCMA-exposure-risk-assessmentfactsheet.pdf].

Wakita, H., Rey, P., \& Schmitt, R. A. (1971). Abundances of the 14 rare-earth elements and 12 other trace elements in Apollo 12 samples: five igneous and one breccia rocks and four soils. In Lunar and Planetary Science Conference Proceedings (Vol. 2, p. 1319).

Wang, Y., Zeng, X., Lu, Y., Su, S., Bai, L., Li, L., \& Wu, C. (2015). Effect of aging on the bioavailability and fractionation of arsenic in soils derived from five parent materials in a red soil region of Southern China. Environmental pollution, 207, 79-87.

Warren, G. P., Alloway, B. J., Lepp, N. W., Singh, B., Bochereau, F. J. M., \& Penny, C. (2003). Field trials to assess the uptake of arsenic by vegetables from contaminated soils and soil remediation with iron oxides. Science of the Total Environment, 311(1-3), 19-33.

Wen, X., Lu, J., Wu, J., Lin, Y., \& Luo, Y. (2019). Influence of coastal groundwater salinization on the distribution and risks of heavy metals. Science of The Total Environment, 652, 267277.

World Health Organization (WHO) (2011). Evaluations of certain contaminants in food. Seventysecond report of the Joint FAO/WHO Expert Committee on Food Additives. WHO technical report series; no. 959.

Yang, Z., Lu, W., Long, Y., Bao, X., \& Yang, Q. (2011). Assessment of heavy metals contamination in urban topsoil from Changchun City, China. Journal of Geochemical Exploration, 108(1), 27-38.

Yu, H. Y., Li, F. B., Liu, C. S., Huang, W., Liu, T. X., \& Yu, W. M. (2016). Iron redox cycling coupled to transformation and immobilization of heavy metals: implications for paddy rice safety in the red soil of South China. In Advances in Agronomy (Vol. 137, pp. 279-317). Academic Press.

Zhang, Z., Juying, L., Mamat, Z., \& QingFu, Y. (2016). Sources identification and pollution evaluation of heavy metals in the surface sediments of Bortala River, Northwest China. Ecotoxicology and Environmental Safety, 126, 94-101. 